\section{Commentary: Reversibility of aortic valve stenosis?}

\author{
Ari A. Mennander, MD, PhD
}

Statins are very liberally used for their anti-inflammatory and lipid-controlling properties. ${ }^{1}$ Some other statinrelated features are associated with protein degradation during skeletal muscle myopathy, ${ }^{1}$ amyloid formation, ${ }^{2}$ and even cancer. ${ }^{3}$ Would it be possible to harness statinrelated protein degradation to treat aortic valve calcification and stenosis once the degenerative cardiovascular process has already commenced?

The experimental study by Jarrett and colleagues ${ }^{4}$ in this issue of the Journal is based on stimulating Toll-like receptor 4 (TLR4), a component of the innate immune system found in calcified aortic valve interstitial cells. This was achieved by adding lipopolysaccharide on cultured aortic valve interstitial cells procured from patients with idiopathic dilated cardiomyopathy. Lipopolysaccharide is a well-known synthetic inducer of the TLR4-associated inflammatory cascade, leading to calcium accumulation through cell osteogenesis. The phenotypic behavior of isolated human aortic valve interstitial cells was secured by testing the serial cell passages grown in culture. ${ }^{5}$ Knockdown of postreceptor signaling proteins was elegantly performed to control the downstream signaling pathway of TLR4. Immunoblotting served to identify specific proteins involved. TLR4 was measured by enzyme-linked immunosorbent assay. The study showed that simvastatin inhibited calcium deposits and blocked the TLR4 pathway associated with deactivation of nuclear factor $\kappa$ light-chain enhancer of activated B cells.

The in vitro approach has the inherent limitations associated with cell cultures in general. Blood circulation does not exist in the experimental model. Immunologic interference of neighboring cells is minimized to include only the cultured cells on a dish. For most clinicians, the potential

\footnotetext{
From Tampere University Heart Hospital and Tampere University, Tampere Finland. Disclosures: Author has nothing to disclose with regard to commercial support.

Received for publication Oct 24, 2019; revisions received Oct 24, 2019; accepted for publication Oct 24, 2019; available ahead of print Nov 13, 2019.

Address for reprints: Ari A. Mennander, MD, PhD, Tampere University Heart Hospital, SDSKIR, PL 2000, Tampere Finland (E-mail: ari.mennander@sydansairaala. fi).

J Thorac Cardiovasc Surg 2021;161:e273-4

$0022-5223 / \$ 36.00$

Copyright (C) 2019 by The American Association for Thoracic Surgery https://doi.org/10.1016/j.jtcvs.2019.10.138
}

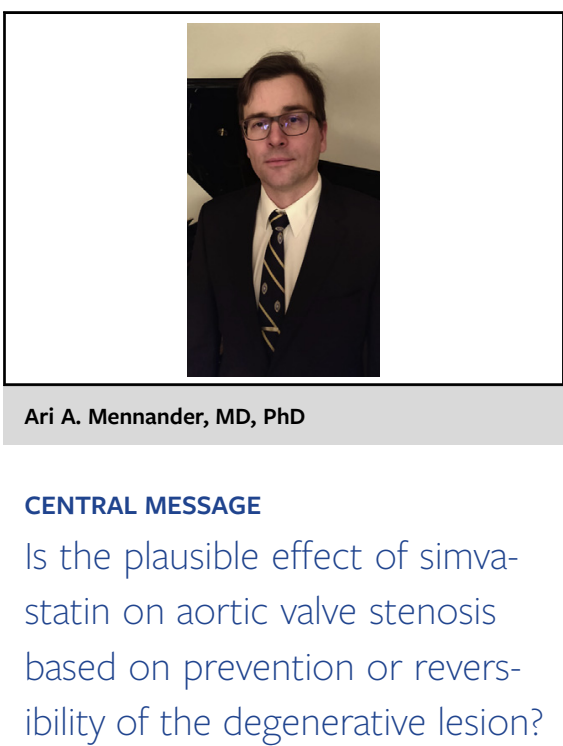

for interstitial cells to proliferate, grow and adhere to petri dish in vitro is a big mystery. The setup is a crude version of the real human body, which encompasses heterogeneity of metabolism, pathology, immunology, and physiology. The stimulation of TLR4 occurs in vivo by other as yet unknown mechanisms, but oxidized cholesterol and presumably some bacteria may act as activators of the receptor. Although this study sought the end-stage osteogenic outcome of the cultured cells, the detailed inflammatory pathway activation itself remains unclear.

The timing of adding simvastatin in the culture may be crucial. One further option to study the effect of simvastatin could now be to establish an animal model that includes controlled timing of the treatment in relation with the development of the acquired aortic valve stenosis. Detailed information on whether simvastatin acts on the cell membrane and the cell endosome may also be further investigated by blocking specific signaling downstream cascade molecules.

Although TLR4-mediated inflammation and degeneration may be a powerful pathway leading to osteogenesis, it may not be the only path leading to aortic valve stenosis. The chronic nature of the disease may encompass other mechanistic pathways in addition to proinflammatory and anti-inflammatory factors. Two pertinent questions remain: Is the effect of simvastatin based on its capacity to prevent aortic valve stenosis? ${ }^{6}$ Or is simvastatin excitingly increasing the degradation of proteins regulating the degree of existing aortic valve stenosis? In other words, can simvastatin be harnessed safely to serve in both prevention and degradation of stenotic lesions of the aortic valve? 


\section{References}

1. Adhyaru BB, Jacobson TA. Safety and efficacy of statin therapy. Nat Rev Cardiol. 2018; 15:757-69.

2. Li HH, Huang CN. Neuroprotective effects of statins against amyloid $\beta$-induced neurotoxicity. Neural Regen Res. 2019;13:198-206.

3. Kou X, Jiang X, Liu H, Wang X, Sun F, Han J, et al. Simvastatin functions as a heat shock protein 90 inhibitor against triple-negative breast cancer. Cancer Sci. 2018; 109:3272-84.

4. Jarrett MJ, Yao Q, Venardos N, Weyant MJ, Reece TB, Meng X, et al. Simvastatin down-regulates osteogenic response in cultured human aortic valve interstitial cells. J Thorac Cardiovasc Surg. 2021;161: e261-71.

5. Meng X, Ao L, Song Y, Babu A, Yang X, Wang M, et al. Expression of functional Toll-like receptors 2 and 4 in human aortic valve interstitial cells: potential roles in aortic valve inflammation and stenosis. Am J Physiol Cell Physiol. 2008;294: C29-35.

6. Rajamannan NM, Subramaniam M, Springett M, Sebo TC, Niekrasz M, McConnell JP, et al. Atorvastatin inhibits hypercholesterolemia-induced cellular proliferation and bone matrix production in the rabbit aortic valve. Circulation. $2002 ; 4: 2660-5$.
See Article page e261.

\section{Commentary: Closing in on aortic stenosis}

\author{
David D. Yuh, MD, FACS, FACC
}

Jarrett and colleagues ${ }^{1}$ have methodically contributed to a better understanding of the complex processes underlying degenerative calcific aortic stenosis (AS). In this most recent investigation, they build upon previous work, which established (1) a differential response of aortic valve interstitial cells (AVICs) to Toll-like receptor 4 stimulation, inducing an inflammatory osteogenic phenotype characteristic of degenerative $\mathrm{AS},{ }^{2}$ and (2) the downregulation of this process by simvastatin. ${ }^{3}$ In rigorously demonstrating the anti-inflammatory effect of simvastatin on mechanistic pathways leading to Toll-like receptor 4-induced osteogenic activity and corresponding calcium deposition in human AVICs in vitro, the group of Jarret and colleagues adds degenerative AS to the growing list of pathologies associated with aging and frailty resulting from chronic inflammatory states.

However, the significance of these findings goes well beyond the notion of prophylactically treating degenerative AS with statins. The processes identified experimentally with calcific degenerative AS are multiple and variegated, including endothelial dysfunction,

From the Department of Surgery, Stamford Hospital, Stamford, Ct.

Disclosures: Author has nothing to disclose with regard to commercial support.

Received for publication Oct 28, 2019; revisions received Oct 28, 2019; accepted for publication Oct 28, 2019; available ahead of print Nov 20, 2019.

Address for reprints: David D. Yuh, MD, FACS, FACC, Department of Surgery, Stamford Hospital, 1 Hospital Plaza, P.O. Box 9317, Stamford, CT 06902 (E-mail: DYuh@stamhealth.org).

J Thorac Cardiovasc Surg 2021;161:e274-5

$0022-5223 / \$ 36.00$

Copyright (c) 2019 by The American Association for Thoracic Surgery

https://doi.org/10.1016/j.jtcvs.2019.10.161
Check for updates

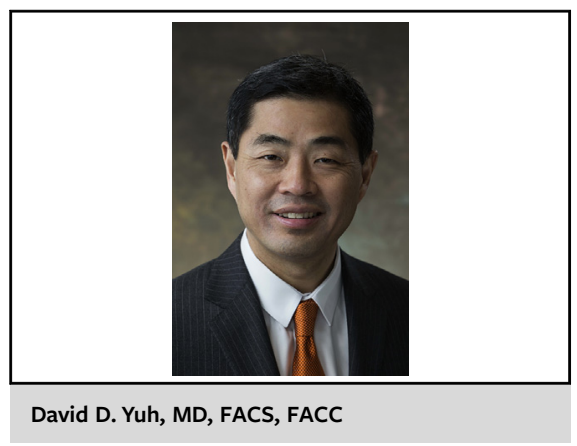

CENTRAL MESSAGE

Continued characterization of

the interactions between the

biomechanical and molecular

mechanisms behind degenera-

tive calcific aortic stenosis may

lead to effective preventative

treatment strategies.

inflammation, endothelial-mesenchymal-transition, angiogenesis, apoptosis, extracellular matrix remodeling, fibrosis, and osteogenesis. ${ }^{4}$ Although the premise that degenerative AS could be prevented simply with the early use of statins is plausible, this "magic bullet" would seem improbable, particularly since there is no convincing evidence that a lower incidence of AS has been observed among the vast number of individuals taking statins for cardiovascular risk reduction.

Although the relative prevalence of AS among cardiovascular disease is significant and growing with the aging population, it presently only comprises $2.8 \%$ of those aged 75 years or older, ${ }^{5}$ rendering impractical the notion of broadly prescribing statins solely to prevent degenerative 